\title{
Social Order Aspects in the Law Enforcement Efforts to Overcome Conflicts of Freedom of Religions and Beliefs
}

\author{
Rini Fidiyani \\ Faculty of Law, Universitas Negeri Semarang (UNNES), Indonesia \\ E-mail: fidiyani.rini@gmail.com
}

\begin{abstract}
Indonesian is based on the vision of Bhineka Tunggal Ika (Unity in Diversity) and the national principle, Pancasila was designed and is found throughout the history by all of the nation founding fathers. The vision has brought the diversity of people from various aspects into unity, one of which is the religious factor or belief that is embraced by each Indonesian citizen. The Indonesian government recognizes 6 (six) religions which are Islam, Catholicism, Christianity, Hinduism, Buddhism and Kong Ho Chu. The freedom of religions and beliefs (KBB) experiences the ups and downs in the interactions of intra and inter religious communities. According to data from the Commission on Human Rights of the Republic of Indonesia, there are several cases of complaints of rights violations of KBB in 2015, totaling 87 complaints. This number increased when compared to that of 2014 which only amounted to 74 complaints (an average of 6 complaints/month). In practice, the causing factor of the conflicts in freedom of religions and beliefs is the intolerance that put fellow believers and other believers in jeopardy. The purpose of this paper is to map and analyze the aspects of social order in the efforts to uphold the law to overcome conflicts of freedom of religions and beliefs in the cities of Central Java. The favorable aspect of social order is a form of tolerance that is safe and opens a dialogue of mutual respect as establishing a right, which later will give a positive impact to the state law enforcement that is more just in dealing with KBB. This research was carried out with the qualitative method through a socio legal research approach, especially the legal anthropology, which is empirical law to overcome the KBB conflicts that emerge in several places.
\end{abstract}

Keywords—social order aspects; diversity; freedom of religions and beliefs

\section{INTRODUCTION}

The diversity of Indonesian people is an inevitable condition which needs to be nurtured and directed together to build a noble national civilization, one of which is the diversity of freedom of religions and beliefs $(\mathrm{KBB})$ which is harmonious. The freedom of religions and beliefs has been regulated by the state constitution firstly through; the article 28 letter E paragraphs (1) and (2); the article 28 letter I paragraph (2); the article 28 letter E paragraph (4), the article 29 paragraph (2) of the 1945 Constitution; and secondly through; the Act Number 39 of 1999 concerning Human Rights. The right to embrace a religion or a belief is the most important thing and it is not a right granted by the State, which is why it is called a non derogable right which must be guaranteed and protected by the State for every citizen under any circumstances (Siti Musdah Muliah, 2007, p.3).

The government has formed a forum that serves as a facilitator to overcome the vulnerability of the KBB conflicts in almost every city, regency, and provincial city. The forum is called the Forum Kerukunan Umat Beragama (Forum for Religious Harmony) (FKUB), consisting of 21 provinces, 110 regencies and 29 cities, which demands the FKUB management to realize the harmonious and tolerant lives between religion communities (Nawala, The Wahid Institute, p.1). This forum does not stand alone. There are still possibilities for other forums coming from non-governmental organizations (NGOs) who care and carry out advocacy against the KBB conflicts, such as Setara Institute.

There have been the ups and downs of KBB conflicts in several regions according to the data found by the Wahid Institute, the Commission for Human Rights and Setara Institute. According to them, there are 5 provinces with the highest potential of KBB conflicts. The provinces are ranked from the highest to the lowest: West Java, Special Capital District of Jakarta, Aceh, Special District of Jogjakarta, and East Java. The KBB conflicts easily ignite some dissent movements, divide the national unity and integrity which threaten the disintegration of the nation and the country. They also trigger a threat of radicalism and terrorism.

This article will analyze the content of social order in the form of a tolerance that is safe and opens a forum of mutual respect by internalizing and externalizing the norms of social order. This was done in the hope that in the future, it will to be able to strengthen state law enforcement in overcoming both prevention of potential conflicts and the existing conflicts of freedom of religions and beliefs in Indonesia for all of the law enforcers, government apparatus and the public in general. 


\section{RESEARCH METHOD}

The method used is a qualitative method through a sociolegal research approach, especially the legal anthropology, which is a social science study which is not doctrinal and empirical law in nature. The law is not regarded as the law in books instead the law that exists in the society (law in society) and it is the result of interactions of human (law in human interaction) both who are involved in the conflict and who try to prevent and overcome the KBB conflicts. The focus of this research is in the forms of words and actions, supported by additional data such as documents and others. All data are processed using interactive and non-interactive methods, and then analyzed using interactive analysis models.

\section{RESULT AND DISCUSSION}

Some actors that triggered the KBB conflicts according to the data found by The Wahid Institute (2014) consisting of $80(51 \%)$ events which involved 98 (52\%) statesmen; while other $78(49 \%)$ events involved 89 (48\%) nonstatesmen. The Setara Institute recorded, out of 236 forms of violation actions of freedom of religions and beliefs, there were 98 of the state actions that involved state administrators as the actors, compared to 138 actions carried out by non-state actors. Compared with the last year's data, the violations conducted by the state actors experienced a significant increase. Previously there were "only" 39 actions, but the violations increased to 98 in 2015. Cumulatively the percentage of action classification based on the actors has not much changed for years. The community groups always occupy the highest rank of violation actors of freedom of religions/beliefs (Halili, 2016: 37-38). The National Commission of Human Rights (Komnas HAM) (2015: 8) actually recorded nearly $70 \%$ of KBB violations were committed by the state (Fidiyani, 2016).

There are some issues that trigger the KBB conflicts, firstly, the problem of houses of worship establishment. Problems concerning the establishment or construction of houses of worship recorded by the National Commission on Human Rights were among others:

a. The prohibition of the Batuplat mosque construction in Kupang - NTT;

b. The prohibition of the Mushalla As Syafiiyah construction in Denpasar city;

c. The activity discontinuance of 19 churches in Aceh Singkil;

d. The sealing of 7 churches in Banda Aceh;

e. The construction discontinuance of a church in Bandung;

f. The sealing of 7 churches in Cianjur

Whereas according to the Setara Institute (2016: 50-

101) there were several cases regarding the establishment of places of worship in 2015.

a. The sealing of the Ahmadiyah mosque in West Java, for examples:
1) Al Furqon Mosque of JAI Kersamaju Branch, Kersamaju Village, Cigalontang, Tasikmalaya. It has been sealed since March 31, 2015 - today.

2) JAI Istiqomah Mosque, Banjar City, which has been sealed since September 29, 2011 - today.

3) A JAI mosque of Tolenjeng Branch, Tasikmalaya regency. It has been sealed since 2003 - today.

4) Basyarat Mosque of JAI Sukaraja. It has been sealed since August 31, 2007 - today.

5) $\mathrm{Al}$ Mahmud Mosque of JAI Singaparna, Tasikmalaya. It has been sealed since 2013 today.

6) JAI Mosque of Ngampang Branch, Cilawu, Garut regency. It has been sealed since September 26, 2014 - today.

b. The Tolikara Case in Manokwari, Papua

c. Anti-Shi'a Declaration in various places

d. The case of sealing 3 churches in Bekasi

e. The case of church attacka in Aceh Singkil

Secondly, legal protection against certain faith adherents; The national commission for human rights (Komnas HAM, 2015, p. 6) stated that the numbers of victims of violations of the right to $\mathrm{KBB}$ from a group of believers are 7 cases as actors of $\mathrm{KBB}$ violations carried out by state officials against Aji Saka followers in Rancagong Village, Legok sub-district, Tangerang regency, Banten. The followers of Aji Saka were accused to have committed blasphemy. Even though Aji Saka is a sect of belief. Therefore, it cannot be properly labeled as a blasphemy. Sapta Dharma's believers received a terror that their place of worship would be burned down on November 10, 2015 at Blando hamlet, Plawangan village, Kragan sub-district, Rembang as a report of the Central Board of the Union of Sapta Dharma Community. Setara Institute (2015) noted that there were 2 cases of violations of the right of KBB against the believers. And third, appreciation towards differences (understanding/teachings, sects, in one religion and hate speech) show a lack of respect for differences. The competition and mutual blame between the Salafi and the Wahabi, the Sunni and the Shia, Islam and Ahmadiyah are still ongoing. The published MUI fatwa on the prohibition of pluralism adds to the list of new problems that plague religious communities, especially religions that have many schools or sects (Islam). Hate speech is also one of the factors that causes this country to often be in an uncertain condition in religious life. In social media, there are many posts containing insults to a certain religion, prophet, scholar, religious leader which can easily be found on the internet. The power of mass media and electronics is capable of dividing the nation. This condition can be mapped as the source of the problem because it involves ignoring the social order by the adherents between the religious communities even by state actors who ideally provide examples of the application of the social order in the form of tolerance that is safe and opens a forum for democratic dialogue. 


\section{A. Internalizing Social Order}

Social order is an order that always lives and develops in human life in the society. It is literally an organized, harmonious, and dynamic social life. It is based on the moral values that each human being has a compassion for others.

To sustain their lives, the society needs to fulfil their biological, economic, and social needs. Their social need can be in the form of the availability of social order and legal order as a means to balance the clashing interests among the groups in realizing an orderly and prosperous society. There are 2 (two) types of social order deriving from the moral values of each human being in KBB, including:

1. Safe tolerance

The term tolerance comes from Latin, that is tolerantia which means patience, gentleness of heart. Whereas in English, tolerance means the quality of patience or circumstance towards opinions, beliefs, behaviors, and customs that are different from what a person has (Misrawi, Zuhairi, 2010, p . 15) . Tolerance is actually owned by every human being regardless of what religion or belief he or she embraces. However, it can be translated by each religious or belief leader into active tolerance and even intolerance in KBB. The content of tolerance includes (Abdullah Hadziq et al., 2009, pp. 5-6):

(1). the recognition of the rights of others; mental attitude to recognize the rights of others in determining their respective attitudes and behavior without violating the rights of others;

(2). respect to others' beliefs; a belief is acquired because it is embedded in the heart and strengthened by certain bases of revelation and rational thinking. It is difficult to influence and change one's belief so there needs to be awareness to respect the beliefs of others;

(3). agreement in disagreement without hostility;

(4). understanding each other; the main thing in tolerance;

(5). awareness and honesty; originating from a pure inner attitude in which there is no contradiction between the heart and the actions done.

(6). Pancasila Philosophy; the foundation or principle of the state as a result of consensus which is practically accepted by all Indonesian people.

In addition to the content or scope of tolerance, there are also models of tolerance, firstly, passive or inclusive tolerance, an attitude of accepting differences as factual because each human being is different in terms of their thoughts and actions; secondly, active tolerance, involving oneself to others regardless the differences and diversity, or in a more concrete term, a safe tolerance. According to Tore Lindholm (Editor) (2010, 139), a safe tolerance means tolerance in which someone actively and concretely involved in disaster relief and even wars among interfaith to be anti-indifference, because he or she thinks that his or her fellow human beings require attention and affection. A concrete example of the events that befell the Rohingya ethnic in Myanmar is the systematic ignorance and ignorance of genocide from the State apparatus and even the leaders of developed countries.
Safe tolerance is carried out through internalization via educational media on the values of Pancasila (Bunyamin Maftuh, 2008, p. 135). The internalization of Pancasila values can practically be achieved by continuous education, motivating, looking for paradigmatic ways to build harmony. The three steps of internalization mentioned above are carried out by academics, families of religious leaders and formal parties, among others, and the law apparatus. The government apparatus has to firstly design harmony. And then, we move on to the way of thinking, how to speak, act, behave to realize religious harmony and belief. (Romo Aloysius Budi Purnomo, Pr, July 24, 2018)

2. Opening a forum for dialogue that is mutually respectful democratically

The word dialogue comes from the Greek word dialogos which means between two parties or dual speech to exchange views, opinions and values of thought ideas. The psychological principle of a dialog is based on true dialogue which contains openness to other parties, willingness to speak and give responses to other parties, and mutual trust in which both parties agree to provide correct information in their own way. (D. Hendropuspito, 1983, p.172-173)

\section{B. The Content of Social Order which Strengthens KBB Law Enforcement}

A broader definition of law enforcement activities covers all of the activities that are intended to ensure the law as the normative method means that regulates and binds on the subject of law in all aspects of social life and a state which is truly and sincerely adhered and properly enforced. (Satjipto Rahardjo, 2006, p.196). The law enforcement in terms of KBB requires several supporting factors to run smoothly, among others (Soerjono Soekanto, 2004, p.24) :

1. Legal Factors (Law)

Regarding the application of the law, there are several principles whose purpose is to ensure that the law has positive impacts. These principles include:

a. the law which does not apply retroactively;

b. the law which is made by the higher authorities;

c. having a higher standing;

d. the specific laws aside from the general law, if the law is made by the same maker;

e. the current law which invalidates the previous law;

f. the law which cannot be contested;

g. the law which serves a means to achieve spiritual and material welfare for either the community or an individual, through preservation or renewal (innovation).

2. Law Enforcement Factors

Legal officers are required to be able to communicate and get an understanding of the target group beside being able to carry out or play their given roles. There are obstacles that are faced by the legal apparatus, they are:

a. limited ability to place themselves in the role of other parties with whom they interact;

b. the relatively low level of aspiration; 
c. very limited excitement to think about the future, so it is very difficult to make projections.

d. no ability to delay the fulfilment of certain needs, especially material needs.

e. the lack of innovative power that is closely related to conservatism.

3. Facility Factors and Support Facilities

There are not enough facility factors and support facilities both in the form of material, human resources that are conscientious and professional as well as organizational managerial

4. Community Factors

Public has a tendency to interpret the law and even identify it as the officers (in this case law enforcers as individuals). One of the consequences is that the law either it is good and bad law will always be associated with the behavior pattern of the law enforcers.

5. Cultural Factors

Cultural factors include the underlying values of the applicable law, both adhered to and violated. The value pairs that influence the law are as follows: (1) the value of order and safety. (2) the value of physic/ material and spiritual/ religious values, and (3) the permanent values/ conservatism and the values of novelty/ innovativeness

In these society and cultural factors, the content of social order in the form of tolerance that is safe and opens a forum for democratic dialogue can facilitate and strengthen the enforcement of law in overcoming the KBB conflicts.

\section{CONCLUSION}

The results of the results and discussion can be summarized that social order contains tolerance that is safe and opens a forum for democratic dialogue providing information and arousing trust for the prevention and the KBB conflicting parties. The above social order can be applied by each citizen by internalizing the values of Pancasila which can be practically carried out by continuous education, motivating, looking for paradigmatic ways to build religious harmony. The law enforcement specifically addressing the KBB conflicts can run accordingly under several factors, including the ability of law enforcement resources in communicating at democratic dialogue forums and community factors and cultural value factors in the form of safe tolerance and democratic dialogue forums for those who are involved in KBB conflicts.

\section{REFERENCES}

[1] Aloysius Budi Purnomo, Pr, Romo, July 24, 2018, Results of Interview at Sugiyopranoto Catholic University, Semarang;

[2] eLSA. (2012). An Annual Report on Freedom of Religion and Belief in Central Java 2012. Semarang: ELSA;
[3] eLSA. (2013). An Annual Report on Freedom of Religion and Belief in Central Java 2013. Semarang: ELSA;

[4] eLSA. (2014). An annual Report on Freedom of Religion and Belief in Central Java 2014. Semarang: ELSA;

[5] Fidiyani, Rini. (2016). Liability of State toward Discriminative Act to Adherent. In Marc Groenhuijsen (Eds), Proceedings of International Conference on Victimology and Victim Assistance in Indonesia (pp. 270-290). Purwokerto: Faculty of Law General Sudirman Union;

[6] Fidiyani, Rini. (2016). The Role of the Law in Settling Violations of Freedom of Religion/ Belief, A paper presented at the National Seminar "National Law Development in the ASEAN Economic Community, Surabaya: UNESA Faculty of Law;

[7] Fidiyani, Rini. (2016). The Dynamics of Building Houses of Worship for Minorities in Central Java, A paper presented at the $3^{\text {rd }}$ National Multidisciplinary Science and Call for Papers National Seminar, Semarang: UNSIBANK;

[8] Komnas HAM. (2015). End-of-Year Report of the Special Rapporteur on Freedom of Religion and Belief in the Indonesian National Human Rights Commission, Jakarta: Komnas HAM.

[9] Hadziq Abdullah, Arifin and Eko Wahyu Suryaningsih (eds), 2009, Selected Papers on Interfaith or Inter religion Harmony, $2^{\text {nd }}$ Edition, Semarang: FKUB;

[10] Halili (2016). Politics of Hope but Minimal Evidence, A Condition Report on Freedom of Religion/ Belief in Indonesia 2015, Jakarta: Community Library Equivalent;

[11] Hendropuspito, D, 1983, Sociology of Religion, Yogyakarta, Kanisius;

[12] Lindholm Tore, Editor, 2010, Freedom of Religion or Belief: How Far: A Reference to the Principles and Practices, Kanisius, Yogyakarta;

[13] Nawala, The Wahid Institute, Seeding Plural and Peaceful Islam, Forum or Bureaucracy of Religious Harmony, Number 3/ $2^{\text {nd }}$ year/ July - October 2007;

[14] Maftuh, Benyamin, 200 8, Internalizing the Values of Pancasila and Nationalism in Citizenship Education, Scientific Journal Educianist Volume II No.2 July 2008;

[15] Misrawi, Zuhairi, 2010, Al-Qur'an; the Book of Tolerance, Islamic Thematic Interpretation of Rahmatan lil'alamin, Jakarta: Pustaka Oasis.

[16] Musdah Muliah, Siti, 2007, Human Rights and Religious Freedom, A Paper at Panel Discussion: The Development of Concepts of Crimes Related to Religion in the Renewal of the Criminal Code, Aliansi RKUHP;

[17] Rahardjo, Satjipto, 2006, Other Side of Law in Indonesia, Second Edition, Kompas Book Publishers, Jakarta;

[18] Soekanto, Soerjono, 2004, Factors Affecting Law Enforcement. Fifth Edition. Jakarta: Raja Grafindo Persada, 2004;

[19] The Wahid Institute (2014). The 2014 Annual Report on Freedom of Religion/Belief and Intolerance: Inherited "Debt" of the New Government, Jakarta: The Wahid Institute. 